\title{
Kesaktian Bahasa Indonesia
}

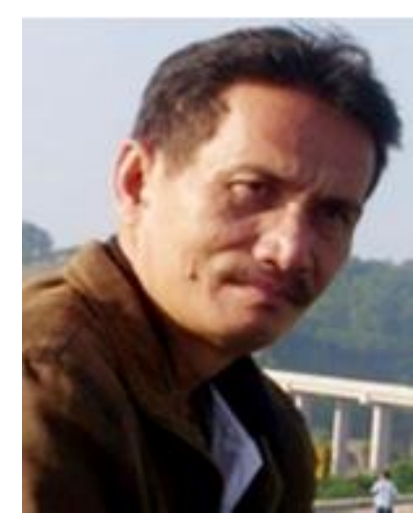

APA jadinya negeri ini jika bukan bahasa Indonesia yang menjadi bahasa nasional? Apa jadinya jika salah satu bahasa daerah yang diangkat menjadi bahasa nasional? Mungkin kita bisa bernasib sama dengan beberapa negara lain yang terus mencari bahasa nasional.

Kita pun perlu mengapresiasi para pendiri negara yang bervisi kebangsaan yang dengan bijak tidak mecantumkan frasa "bahasa Melayu" dalam rumusan Sumpah Pemuda, walaupun yang digunakan adalah unsur bahasa Melayu Riau. Hanya bahasa Melayu dan bahasa Jawa yang berpeluang menjadi bahasa nasional saat perdebatan di Konggres Pemuda II tahun 1928.

Bersyukurlah para pemimpin yang bervisi ke depan itu merumuskan hanya nama bahasa Indonesia yang muncul untuk menyebut bahasa persatuan sekaligus bahasa nasional dalam rumusan Sumpah Pemuda. Pertimbangan bahwa bahasa Melayu yang sudah lama menjadi lingua franca di wilayah Nusantara, berpotensi, dan mudah berkembang adalah masuk akal(Muhamad Fahmi, 2013).

Kenyataannya, rumusan itu telah membius dan menyatukan semangat karena didukung semua unsur saat itu. Bagian kalimat "...menjunjung bahasa persatuan, bahasa Indonesia" seolah-olah menjadi magnet yang sangat kuat untuk mempersatukan seluruh bangsa Indonesia yang memiliki beribu-ribu bahasa daerah. Rumusan yang akomodatif ini sekaligus mengakui keberadaan bahasa-bahasa daerah sebagai pendukung kekuatan bahasa nasional.

\section{Alat Pemersatu}

Peran bahasa Indonesia dalam persatuan bangsa sudah tidak disangsikan lagi. Kita sangat berbangga wilayah negara yang begitu luas dengan bahasa dan budaya setempat yang tersebar di ribuan pulau, bahasa Indonesia terus berkembang dan menjadi satu-satunya bahasa yang diakui sebagai bahasa nasional bagi seluruh warganya. Sekali lagi, bandingkan dengan negara lain yang masih "bertengkar" memperebutkan pengakuan bahasa-bahasa daerah mereka menjadi bahasa nasionalnya. 


\section{Bahasa Internasional?}

Struktur bahasa yang sudah mapan menjadikan bahasa ini mudah dipelajari bagi siapa saja yang belajar. Ini sudah dibuktikan dengan dipelajarinya bahasa Indoneisa di berbagai Negara sehingga tidak berlebihan jika kita optimistis bahasa Indonesia pun berpotensi menjadi bahasa Internasional. Bahasa Indonesia sudah terbukti kuat sehingga kita harus terus mengikis sisa mental inlander kita. Walaupun ratusan tahun kita dijajah Belanda, bahasa kolonial itu tidak bertumbuh dan seolah tidak berbekas di negeri ini. Sebaliknya, bahasa Indonesia semakin perkasa tertanam di segala segi.

\section{"Bahasa" Vicky}

Dari semula saya pun tidak yakin fenomena bahasa Vicky memengaruhi perkembangan bahasa Indonesia. Selama penggunaan bahasa itu hanya terjadi di wilayah hiburan, apalagi hanya untuk lucu-lucuan, maka pennyebarannya hanyalah terbatas pada wilayah mereka. Selanjutnya, bahasa lucu-lucuan itu akan hilang dengan sendirinya jika sudah tidak dianggap lucu lagi. Penggunaan bahasa Vicky tidak akan mampu menggeser kemapanan Bahasa Indonesia, terutama di ragam formal. Sehingga, kekhawatiran beberapa pihak terhadap pengaruh bahasa tersebut terhadap perkembangan bahasa Indonesia saya anggap berlebihan.

Sebenarnya cara berbahasa seperti Vicky sudah biasa dalam berbahasa. Perpindahan bahasa (switch code) dan percampuran bahasa (mix code) biasa terjadi jika si penutur itu adalah seorang dwibahasa, terutama dalam mix code. Sementara dalam alih kode bisa terjadi misalnya karena ada pihak ketiga yang tibatiba muncul menggunakan bahasa kedua itu, penggunaan alih kode pun tidak terhindarkan. Namun, kasus Vicky memang agak berbeda. Hampir dua ciri peristiwa bahasa itu tidak terjadi. Secara leksikal bahasanya bisa dimengerti tetapi secara gramatikal kacau. Mungkin kalau diibaratkan, bahasa Vicky adalah bahasa Google Translate. Atau, mungkin Vicky merasa grogi saat bicara di depan umum padahal dia ingin menunjukkan keintelekannya walaupun belum mampu dengan baik berbahasa verbal dua bahasa itu. Demikian juga dengan 'Mbah Google'. Mesin terjemahan milik Google ini akan kebingungan jika menerjemahkan kalimat bahasa Indonesia yang kompleks.

Kita berharap tidak akan ada perdebatan bahasa Indonesia sebagai bahasa nasional. Kita tidak perlu memunculkan hari kesaktian bahasa Indonesia. Kita semua sudah mengakui bahasa Indonesia adalah alat pemersatu bangsa yang sudah teruji kesaktiannya. Tidak aka ada perdebatan seperti halnya penetapan hari kesaktian Pancasila dan hari lahir Pancasila.

-Suharto, dosen Sendratasik FBS Unnes

Telah dimuat di Gagasan Unnes tanggal28 Oktober 2013 (http://unnes.ac.id/gagasan/kesaktianbahasa-indonesia/)

\section{REFERENCE}

Suharto. (1997). Musik dan Bahasa. Media FBS IKIP Semarang, 20(4), 286-393

Suharto, S. (2011). Music And Language: A Stress Analysis of English Song Lyrics. Harmonia: Journal Of Arts Research And Education, 5(3). doi:http://dx.doi.org/10.15294/harmonia.v5i3.821 
Ratna Supradewi. (2010). OTAK, MUSIK, DAN PROSES BELAJAR. BULETIN PSIKOLOGI, 18(2), 58-68

Muhamad Fahmi. (2013). Isi Teks Sumpah Pemuda oleh Muhamad Fahmi - Kompasiana.com.

Retrieved October 4, 2017, from https://www.kompasiana.com/mfahmi/isi-teks-sumpahpemuda_552a97146ea8341a51552d15 